\title{
Mn(III)-Mediated Synthesis of Pyridines
}

Key words

pyridines

vinyl azides

cyclopropanols

manganese

$\mathrm{Mn}(\mathrm{acac})_{3}(1.7$ equiv), $\mathrm{AcOH}$

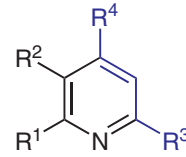

3

$30-84 \%$ yield

24 examples

$\mathrm{R}^{1}=\mathrm{Ph}, 2-\mathrm{MeOC}_{6} \mathrm{H}_{4}, 4-\mathrm{MeOC}_{6} \mathrm{H}_{4}, 4-\mathrm{MeO}_{2} \mathrm{CC}_{6} \mathrm{H}_{4}$, 2-Naph, $N$-Ts-pyrrol-2-yl, N-Ts-indol-2-yl, $\mathrm{CO}_{2} \mathrm{Et}$ $\mathrm{R}^{2}=\mathrm{H}, \mathrm{Me}, \mathrm{Ph}$

$\mathrm{R}^{1}-\mathrm{R}^{2}=-\left(\mathrm{CH}_{2}\right)_{6}-$

$\mathrm{R}^{3}=c-\mathrm{Pr}, c-\mathrm{Bu}, \mathrm{CH}_{2} \mathrm{Bn}, \mathrm{N}$-Bn-piperidin-2-yl, $(E)-\mathrm{CH}=\mathrm{CHPh}, \mathrm{C} \equiv \mathrm{CPh}, \mathrm{Ph}, 2-\mathrm{BrC}_{6} \mathrm{H}_{4}, 4-\mathrm{BrC}_{6} \mathrm{H}_{4}, 4-\mathrm{PhC}_{6} \mathrm{H}_{4}, \mathrm{CO}_{2} \mathrm{Me}, \mathrm{SiMe}_{2} \mathrm{Ph}$ $\mathrm{R}^{4}=\mathrm{H}, \mathrm{Me}, \mathrm{Ph}$<smiles>C=C([NH])P</smiles><smiles>OC12C=CC([P])C1C2</smiles>

$\mathrm{Mn}(\mathrm{acac})_{3}(10-40 \mathrm{~mol} \%), \mathrm{AcOH}$

$\mathrm{MeOH}$, r.t., $1 \mathrm{~h}$
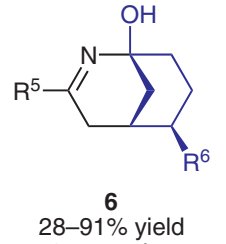

$\mathrm{R}^{5}=\mathrm{Ph}, \mathrm{N}$-Ts-pyrrol-2-yl, N-Ts-indol-2-yl $\mathrm{R}^{6}=\mathrm{H}$, vinyl, $\mathrm{Ph}, \mathrm{CH}_{2} \mathrm{OMOM}$

Significance: Reported here is the $\mathrm{Mn}(\mathrm{III})$-mediated synthesis of pyridines $\mathbf{3}$ from vinyl azides $\mathbf{1}$ and cyclopropanols 2. Sub-stoichiometric amounts of $\mathrm{Mn}(\mathrm{acac})_{3}$ may be used in the reaction, although an oxidant such as DDQ or molecular $\mathrm{O}_{2}$ must be added. Ultimately, the use of excess $\mathrm{Mn}(\mathrm{acac})_{3}$ led to higher yields and increased operational simplicity. Alkyl-, aryl-, heteroaryl-, alkenyl- and alkynyl-substituted pyridines may all be prepared using this methodology. When bicyclic cyclo-propanols 5 were used as substrates under catalytic Mn(III) conditions, 2-azabicyclo[3.3.1]non-2-en-1ols 6 were formed in excellent yields in most cases. A radical cyclization mechanism is proposed without experimental evidence.
Comment: Nitrogen-containing heterocycles are prevalent in a wide variety of natural products and drug molecules. The pyridine ring is particularly evident in bioactive molecules (see Book below), including alkaloids (nicotine) and herbicidal (paraquat dichloride), pesticidal (Densil S) and therapeutic agents (isoniazid). The current divergent method allows for the rapid and versatile synthesis of polysubstituted pyridines or azabicycles from readily available starting materials. The use of stoichiometric amounts of $\mathrm{Mn}(\mathrm{acac})_{3}$ and the potentially explosive azides may, however, limit the utility of this methodology in large-scale applications.

Book: D. Spitzner, In Science of Synthesis, Vol. 15; D. Black, Ed.; Georg Thieme Verlag: Stuttgart,

2004, 11-284. 